\title{
Effects of Temperature and pH on Fusarium oxysporum and Soybean Seedling Disease
}

\author{
David R. Cruz, Leonor F. S. Leandro, and Gary P. Munkvold ${ }^{\dagger}$ \\ Department of Plant Pathology and Microbiology, Iowa State University, Ames, IA 50011
}

\begin{abstract}
Fusarium oxysporum $(F o)$ is an important pathogen that reduces soybean yield by causing seedling disease and root rot. This study assessed the effects of $\mathrm{pH}$ and temperature on $F o$ fungal growth and seedling disease. In an in vitro assay, 14 Fo isolates collected from symptomatic soybean roots across Iowa in 2007 were grown on artificial culture media at five $\mathrm{pH}$ levels $(4,5,6,7$, and 8$)$ and incubated at four temperatures $(15,20$, 25 , or $30^{\circ} \mathrm{C}$ ). In a rolled-towel assay, soybean seeds from $\mathrm{Fo}$-susceptible cultivar Jack were inoculated with a suspension of a pathogenic or a nonpathogenic Fo isolate; both isolates were previously designated for their relative aggressiveness in causing root rot at $25^{\circ} \mathrm{C}$. The seeds were placed

between temperature and $\mathrm{pH}(P<0.05)$ for in vitro radial growth and root rot severity. Isolates showed the most in vitro radial growth after incubation at $\mathrm{pH} 6$ and $25^{\circ} \mathrm{C}$. For the rolled-towel assay, the pathogenic isolate caused the most severe root rot at $\mathrm{pH} 6$ and $30^{\circ} \mathrm{C}$. Gaussian regression analysis estimates for optimal conditions were $\mathrm{pH} 6.3$ at $27.1^{\circ} \mathrm{C}$ for maximal fungal growth and $\mathrm{pH} 5.9$ at $30^{\circ} \mathrm{C}$ for maximal root rot severity. These results indicate that optimal $\mathrm{pH}$ and temperature conditions are similar for $F o$ growth and disease in soybean seedlings and suggest that Fo may be a more important seedling pathogen when soybeans are planted under warm conditions in moderately acidic soils.
\end{abstract} in rolled germination paper, and the rolls were incubated in all combinations of buffer solutions at four $\mathrm{pH}$ levels $(4,5,6$, and 7), and four temperatures $\left(15,20,25\right.$, or $\left.30^{\circ} \mathrm{C}\right)$. There was a significant interaction
Keywords: fungi, field crops, oilseeds and legumes, epidemiology, climate/weather effects
Fusarium oxysporum Schltdl. (Fo) is one of the fungal species most commonly isolated from soybean roots in the soybean producing regions of North America (Díaz Arias et al. 2013a; Ellis et al. 2014; Zhang et al. 2010). Fo has been associated with soybean damping-off, seed and seedling root rot, and vascular wilt (Armstrong and Armstrong 1965; Datnoff and Sinclair 1988; Díaz Arias et al. 2013a, 2013b; Leath and Carroll 1982). Although there is some understanding of $F o$ genetic and phenotypic diversity, including the existence of pathogenic and nonpathogenic isolates and variable levels of resistance among soybean cultivars (Cruz Jimenez et al. 2018; Díaz Arias et al. 2013a; Ellis et al. 2014; Lanubile et al. 2015), the effects of temperature and $\mathrm{pH}$ in the soybean-Fo interaction are unknown. These variations in disease severity may be influenced by abiotic factors such as temperature and $\mathrm{pH}$ that alter host-pathogen dynamics, making it difficult to understand the processes involved in soybean root rot development.

The most suitable $\mathrm{pH}$ for growth for plant pathogenic isolates in the Fusarium genus has been reported in the 3.5 to 7 range (Cochrane 1958; Groenewald et al. 2006; Gupta et al. 2010; Srobar 1978).

Maximal in vitro radial growth in many Fusarium spp. such as $F$. beomiforme, $F$. proliferatum, and $F$. verticillioides has been found at temperatures close to $30^{\circ} \mathrm{C}$ (Marin et al. 1995; Miller and Burke 1985; Nelson et al. 1990). In addition, plant pathogenic $F_{O}$ isolates from other host species have been found to have a maximal radial growth at temperatures between 25 and $28^{\circ} \mathrm{C}$ (Brownell and Schneider 1985; Gupta et al. 2010; Nelson et al. 1990; Webb et al. 2015).

There is evidence of significant interactions between $\mathrm{pH}$ and temperature on fungal radial growth in Fusarium spp. (Chen et al. 2013;

${ }^{\dagger}$ Corresponding author: G. P. Munkvold; munkvold@iastate.edu

Funding: This research was funded by the United Soybean Board and the North Central Soybean Research Program.

The author(s) declare no conflict of interest.

Accepted for publication 7 June 2019.

(C) 2019 The American Phytopathological Society
Marin et al. 1995; Schuerger and Mitchell 1992). In addition, temperature alters the expression of host defense mechanisms favoring resistance or susceptibility reactions (Harling et al. 1988; Stuthman et al. 2007). For example, moderately resistant or highly resistant cultivars of banana, carnation, chickpea, or lettuce become susceptible under high temperatures $\left(>25^{\circ} \mathrm{C}\right)$ after inoculation with their respective Fo f. sp. (Brake et al. 1995; Harling et al. 1988; Landa et al. 2006; Scott et al. 2010). Differences in soil pH might alter Fusarium spp. growth rate, spore attachment on plant roots, and inoculum density, contributing to the expression of wilt symptoms on plants exposed to different temperatures (Chen et al. 2013; Gatch and du Toit 2017; Navas-Cortés et al. 2007; Schuerger and Mitchell 1992).

Mathematical models help to understand the interactions of abiotic factors on pathogens and disease development. Polynomial models have been used to describe temperature and $\mathrm{pH}$ effects on Fusarium wilts under greenhouse and hydroponic conditions in cucumber and mung bean (Chen et al. 2013; Schuerger and Mitchell 1992). Gaussian and quasi-Gaussian models are used to describe spatial dispersion over long distances of spore-bearing vascular plants and rust spores (Skelsey et al. 2008; Soubeyrand et al. 2008). Gaussian models have been used in plant pathology to simulate spore wind dispersal of $P$ hytophthora infestans in potatoes (Spijkerboer et al. 2002) and describe spatial movement of wind-dispersed spores of Gibberella zeae foci on wheat plots (Paulitz et al. 1999; Prussin et al. 2015). Development of a Gaussian model may be useful to describe how these environmental factors influence the development of soybean root rot caused by $F o$.

The goal of this research was to evaluate the importance of $\mathrm{pH}$ and temperature in the development of soybean root rot caused by Fo. Our objectives were to determine the effects of $\mathrm{pH}$, temperature, and their potential interaction on (i) in vitro radial growth, (ii) soybean root rot under growth chamber conditions, and (iii) characterization of $F o$ isolates as pathogenic or nonpathogenic.

\section{Materials and Methods}

Effects of pH and temperature on in vitro radial growth. Fourteen $F o$ isolates collected from symptomatic roots across Iowa were single-spore isolated, identified to species microscopically and by DNA sequencing (Díaz Arias et al. 2013a), phenotypically and 
genotypically characterized (Cruz Jimenez et al. 2018; Ellis et al. 2014), and maintained on dry silica beads at $4^{\circ} \mathrm{C}$ until use. To prepare inoculum for the experiments, the $F o$ isolates were grown on potato dextrose agar (PDA) at $39 \mathrm{~g} /$ liter (Difco, Becton, Dickinson and Co., Spark, MD) at $25^{\circ} \mathrm{C}$ for 4 days, with a 12 -h photoperiod. A $5-\mathrm{mm}$ plug was punched from the PDA culture and transferred to the center of a 90-mm-diameter Petri dish containing differential media with one of five $\mathrm{pH}$ levels $(4,5,6,7$, and 8$)$ and additionally fullstrength PDA medium ( $\mathrm{pH} \sim 6.5$ ).

The media differing in $\mathrm{pH}$ levels were prepared as described by Groenewald et al. (2006). Citrate/phosphate buffer was prepared by titrating $0.1 \mathrm{M}$ citric acid (Amresco, Solon, OH) with $0.2 \mathrm{M}$ $\mathrm{Na}_{2} \mathrm{HPO}_{4} \cdot 12 \mathrm{H}_{2} \mathrm{O}$ (Acros, Springfield Township, NJ) to reach a $\mathrm{pH}$ of 4 or 5 . Phosphate buffer was prepared by titrating $0.2 \mathrm{M}$ $\mathrm{Na}_{2} \mathrm{HPO}_{4} \cdot 12 \mathrm{H}_{2} \mathrm{O}$ (Acros) with $0.2 \mathrm{M} \mathrm{NaH} \mathrm{PO}_{4} \cdot 2 \mathrm{H}_{2} \mathrm{O}$ (Acros) to reach a $\mathrm{pH}$ of 6 or 7 . Boric acid buffer was prepared by titrating $0.2 \mathrm{M}$ boric acid (Fisher, Chicago, IL) with $0.05 \mathrm{M}$ sodium tetraborate $\mathrm{Na}_{2} \mathrm{~B}_{4} \mathrm{O}_{7} \cdot 10 \mathrm{H}_{2} \mathrm{O}$ (Fisher) to reach a $\mathrm{pH}$ of 8 . Once the buffers for $\mathrm{pH} 4,5,6,7$, and 8 were prepared, a basal medium was added to each liter of buffer. The basal medium consisted of $45 \mathrm{~g}$ of sucrose $(\mathrm{C} \& \mathrm{H}$, Crocket, CA), $3 \mathrm{~g}$ of $\mathrm{NaNO}_{3}$ (Sigma-Aldrich), $1.5 \mathrm{~g}$ of $\mathrm{K}_{2} \mathrm{HPO}_{4}$ (Fisher), $0.75 \mathrm{~g}$ of $\mathrm{MgSO}_{4} \cdot 7 \mathrm{H}_{2} \mathrm{O}$ (Sigma-Aldrich), $0.75 \mathrm{~g}$ of $\mathrm{KCl}$ (Fisher), and $0.015 \mathrm{~g}$ of $\mathrm{FeSO}_{4} \cdot 7 \mathrm{H}_{2} \mathrm{O}$ (Fisher). Agar (Difco, Becton, Dickinson and Co.) was added at a rate of $15 \mathrm{~g} /$ liter for $\mathrm{pH}$ buffers 5 , 6,7 , and 8 , with a higher rate of agar of $18 \mathrm{~g} /$ liter for $\mathrm{pH} 4$ owing to the reduced gelling capacity of agar at low $\mathrm{pH}$ (Wetzstein et al. 1994; Yamamoto and Cunha 2007). In addition to the $\mathrm{pH}$ differential media, a full-strength PDA medium at $39 \mathrm{~g} /$ liter $(\mathrm{pH} \sim 6.5$ ) was included in the experiments.

Fo cultures on the $\mathrm{pH}$ differential media and full-strength PDA medium $(\mathrm{pH} \sim 6.5)$ were incubated at four different temperatures $\left(15,20,25\right.$, and $30^{\circ} \mathrm{C}$ ) for 5 days in an incubator (Hoffman Manufacturing, Corvallis, OR) at $65 \%$ relative humidity and in the dark. Diameter of each colony was then measured in two perpendicular directions, and an average of the two measurements was calculated after subtracting the 5-mm diameter of the colonized plug. The experiment was organized in a split-plot in a completely randomized design, in which temperature was the main plot treatment and the $\mathrm{pH}$ differential medium/isolate combination randomized within each chamber was considered as the subplot treatment. There were four replicate Petri dishes per temperature/pH differential medium/ isolate combination, and the experiment was conducted two times.

Effects of $\mathrm{pH}$ and temperature on seedling disease. Fo isolates FO38 and FO42, previously identified as pathogenic and nonpathogenic to soybeans at $25^{\circ} \mathrm{C}$, respectively (Cruz Jimenez et al. 2018; Díaz Arias et al. 2013a; Ellis et al. 2014), were grown on PDA for 7 days at $25^{\circ} \mathrm{C}$, with a 12 -h photoperiod, to promote conidial formation. Macro- and microconidia were collected by rinsing the plates with sterile distilled water and scraping the surface of the cultures with a sterile stick. The suspension was filtered through sterile cheesecloth to remove mycelial fragments. Inoculum concentration was calculated by counting conidia in a hemacytometer (Brightline Hemacytometer, American Optical, Buffalo, NY) under the microscope, and conidial suspensions were adjusted to a concentration of $1 \times 10^{6}$ conidia/ml.

Fifteen seeds of Fo-susceptible cultivar Jack (Cruz Jimenez et al. 2018) were placed on moist towels and individually inoculated with $200 \mu \mathrm{l}$ of the spore solution of FO38 or FO42. Paper towels were moistened with a buffer solution adjusted to $\mathrm{pH}$ levels 4, 5, 6, or 7 using citric acid (Amresco) and sodium hydroxide $(\mathrm{NaOH})$ (Fisher). Each towel was rolled up and placed in a 1,500-ml glass jar containing $250 \mathrm{ml}$ of the respective buffer and incubated for 8 days in growth chambers (Hoffman Manufacturing) at four different temperatures $\left(15,20,25\right.$, and $\left.30^{\circ} \mathrm{C}\right)$ at $65 \%$ relative humidity and with a $12-\mathrm{h}$ photoperiod.

Each roll was considered as an experimental unit, placing one roll per glass jar with 15 seeds or subsamples on each roll. There were three inoculated rolls for each of the $F o$ isolates and three noninoculated rolls for each $\mathrm{pH}$ and temperature treatment combination (4 temperatures $\times 4 \mathrm{pH} \times 3$ inoculation treatments $\times 3$ reps $=$ total
144 experimental units). The experiment was conducted in a splitplot design. Temperature was the main plot treatment, and the combination of differential $\mathrm{pH}$ buffer and isolate randomized in each growth chamber was the subplot treatment. There were three replicate rolls per temperature/pH/Fo isolate combination. The experiment was conducted two times.

Seedlings were rated for root rot using two methods: a disease severity index (DSI) and a visual disease severity scale (1 to 5), as described by Ellis et al. (2011). DSI was calculated as the ratio between the lesion length (discolored or colonized hypocotyl and radicle) and the total plant length, multiplied by 100 . When seeds did not germinate and were completely colonized, they were assigned a DSI value of $100 \%$. The visual 1 to 5 disease severity scale was assessed according to the following ratings: $1=$ germination, no symptoms of disease or colonization on seedling; 2 = germination, little colonization of the seedling, 1 to $19 \%$ of the root with lesions; $3=$ germination, some colonization of seedling, and 20 to $74 \%$ of the root with lesions; 4 = germination, complete colonization of the seedling, and $75 \%$ or more of the root with lesions; and $5=$ no germination, complete colonization of the seed.

Reductions in seedling growth owing to inoculation were calculated by measuring the root weight, root length, and shoot length on each $F o$-inoculated plant, dividing by the average measure of the noninoculated control within each temperature and $\mathrm{pH}$ combination treatment and then multiplying by 100 .

Data analysis. Variances of the raw data for the two experiments of radial growth were compared by using Levene's test for homogeneity under the general linear model procedure (PROC GLM) of SAS version 9.3 (SAS Institute, Cary, NC). Variances of the two experiments were not statistically different according to the test $(P=0.95)$; therefore, the raw data for the two experiments were combined for subsequent analysis. In addition, normal distribution of the residuals was tested under the PROC UNIVARIATE statement. Analysis of variance was performed under PROC GLIMMIX, in which experimental replication, temperature, $\mathrm{pH}$ differential media or full-strength PDA medium, and $F o$ isolates were considered as fixed factors, and the two experimental replications and their interaction with temperature were considered as random effects. In addition, a four-way interaction term between experimental replication, temperature, $\mathrm{pH}$ differential media, and Fo isolates was added as a random effect for the statistical analysis. Mean separation analyses were performed using a Tukey's multiple comparison test $(P=0.05)$.

For the pathogenicity assay, the average of DSI was arcsine transformed, and the disease severity scale was square-root transformed. Analysis of variance was performed under the PROC GLIMMIX statement, in which experimental replication, temperature, $\mathrm{pH}$ buffers, and $F o$ isolates were considered as fixed factors. The two experimental replications and their interaction with temperature were considered as random effects. In addition, a four-way interaction term between experimental replication, temperature, $\mathrm{pH}$ buffers, and $F o$ isolates was added as a random effect for the statistical analysis. Denominator degrees of freedom were calculated by the Satterthwaite method, and mean separation analyses on the transformed data were performed using a Tukey's multiple comparison test $(P=0.05)$. The average raw data of DSI and the visual scale for severity for each of the $F o$-inoculated rolls were used to calculate linear correlation coefficients using the PROC CORR statement.

Exponential, polynomial, logistic, Gompertz, and Gaussian models were tested to describe the radial growth and root rot of Fo under the $\mathrm{pH}$ and temperature levels selected for the experiments. Model selection was based on the following criteria described by Byamukama et al. (2011): low standard error of the estimate, significant $F$ statistics $(P \leq 0.05)$, and high coefficients of determination $\left(R^{2}\right)$. The model that best described and fit the data was selected to obtain parameter estimates.

Gaussian regression analyses for fungal radial growth and DSI were performed for each individual $F o$ isolate using SigmaPlot version 13 (Systat Software, San Jose, CA) under the following function: 


$$
f=a \exp \left\{-5\left[\left(\frac{x-X o}{b}\right)^{2}+\left(\frac{y-Y o}{c}\right)^{2}\right]\right\}
$$

where $a$ is the largest value of the response variable (DSI or fungal radial growth), $X_{O}$ is the temperature value for the maximum $a, Y_{0}$ is the $\mathrm{pH}$ value for the maximum $a$, and $b$ and $c$ are the $\mathrm{pH}$ and temperature ranges for the peak shaped function. Estimated values of temperature and $\mathrm{pH}$ for maximal fungal radial growth and disease severity were obtained by using a nonlinear optimization procedure (solver add-in) in Excel (Microsoft) under the following constraints: $\mathrm{pH}$ range between 4 and 7 and temperature range between 15 and $30^{\circ} \mathrm{C}$.

\section{Results}

Effects of $\mathrm{pH}$ and temperature on in vitro radial growth. Analysis of variance indicated that main effects of temperature, $\mathrm{pH}$, and $F_{O}$ isolate and their interactions were highly significant $(P<0.0001)$ for fungal radial growth. Maximal radial growth was observed at $\mathrm{pH} 6$ at 25 and $30^{\circ} \mathrm{C}$, for isolates $\mathrm{FO} 41$ and $\mathrm{FO} 49(6.39$ and $6.3 \mathrm{~cm}$,

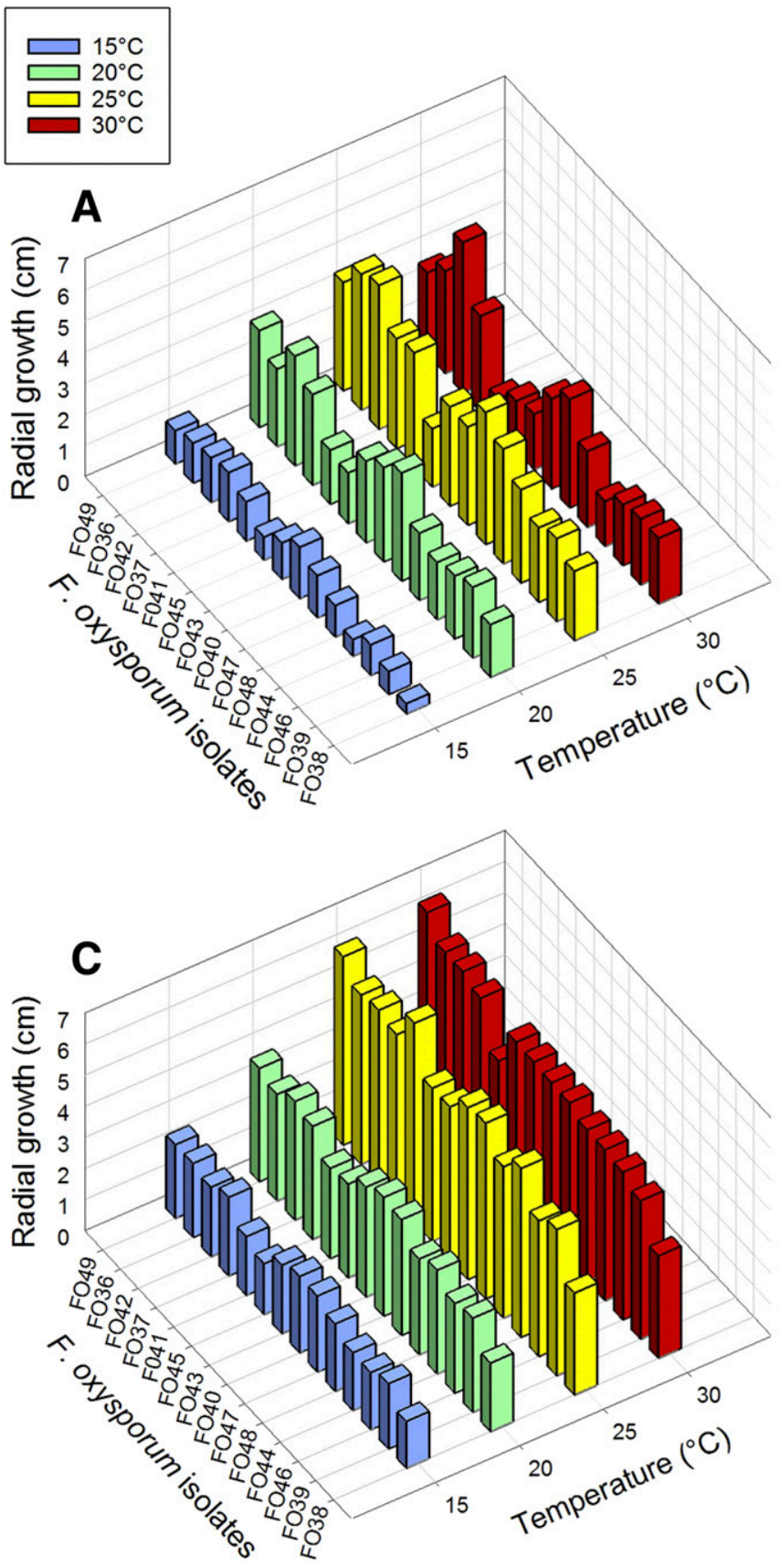

respectively). Minimal radial growth was observed at $15^{\circ} \mathrm{C}$ at $\mathrm{pH} 4$ for isolate FO38 $(0.3 \mathrm{~cm})$ (Fig. 1). No growth was observed at $\mathrm{pH} 8$ for any of the $F o$ isolates evaluated in this study.

On full-strength PDA there was a strong effect of temperature and isolate on radial growth with a significant interaction between these two factors $(P<0.0001)$. Individual isolates had significant differences in their final radial growth. Maximal radial growth was observed at $25^{\circ} \mathrm{C}$ for isolates $\mathrm{FO} 47$ and $\mathrm{FO} 36$ (4.38 and $4.15 \mathrm{~cm}$, respectively). Minimal radial growth was observed at $15^{\circ} \mathrm{C}$ across all isolates, with FO41growing the least $(1.11 \mathrm{~cm})$ (data not shown).

The Gaussian model best described the changes in radial growth across levels of $\mathrm{pH}$ and temperature for all $F_{O}$ isolates, with significant $F$ statistics ranging from 6.8012 to 37.3336 , indicating there was a strong relationship between temperature, $\mathrm{pH}$, and radial growth (Table 1). Coefficients of determination $\left(R^{2}\right)$ from the Gaussian regression analyses varied among isolates, explaining up to $93.1 \%$ of the variation in fungal radial growth. In addition, the Gaussian model
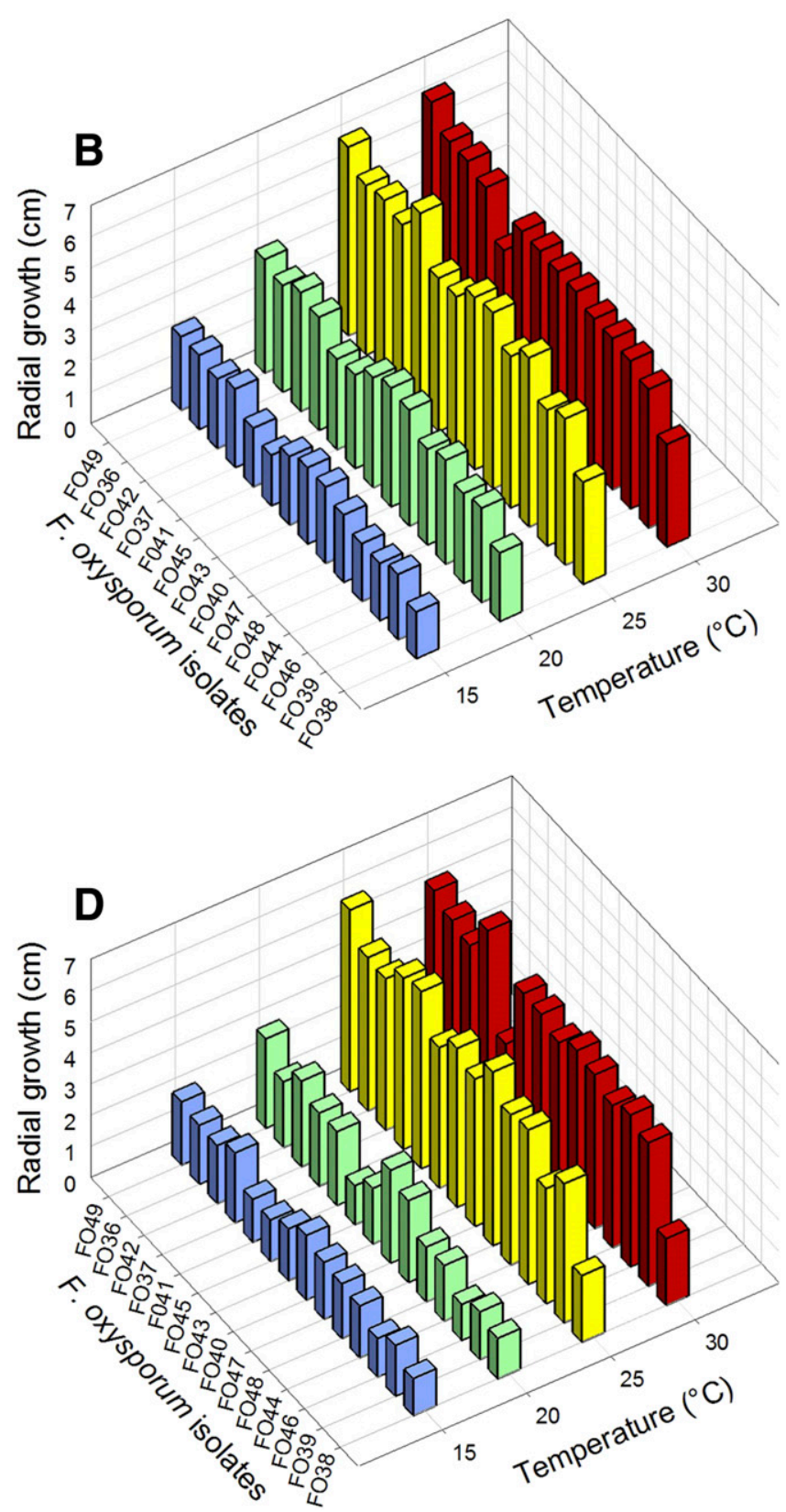

Fig. 1. Radial growth of 14 Fusarium oxysporum isolates with respect to temperature and $\mathrm{pH}$ of the growth medium. A, B, C, and D, Isolates growing in citrate/phosphate buffer set at $\mathrm{pH} 4,5,6$, and 7 , respectively. Data represent the mean values of two experiments with four replicate Petri dishes for each treatment combination. 
had lower standard error of the estimates, with values ranging from 0.3907 to 0.9157 (Table 1), compared with exponential, logistic, and Gompertz models (data not shown).

Estimated values of optimal $\mathrm{pH}$ and temperature for maximal radial growth obtained from the Gaussian regression analysis indicated variation among isolates. $\mathrm{pH}$ estimated values varied between 5.6 and 6.8 , and temperatures varied between 25.4 and $30^{\circ} \mathrm{C}$. A separate regression was performed on the average data of fungal radial growth across $F o$ isolates; the average estimate of $\mathrm{pH}$ and temperature for maximal radial growth over all $F o$ isolates was 6.3 and $27.1^{\circ} \mathrm{C}$, respectively (Table 1, Fig. 2).

Effects of $\mathrm{pH}$ and temperature on seedling disease. According to the analysis of variance, there was a significant effect of isolate $(P<0.0001)$, and the interaction between temperature and isolate was significant $(P<0.0001)$ on DSI, indicating that temperature differentially affected the severity of each particular isolate (Table 2, Fig. 3).

DSI varied across levels of $\mathrm{pH}$ and temperature. For the pathogenic isolate, the highest level of root rot was observed at $\mathrm{pH} 6$ and $30^{\circ} \mathrm{C}(67 \%)$, and the lowest levels of disease severity were observed at $15^{\circ} \mathrm{C}$ at $\mathrm{pH} 4$ and 5 (4.2\%) (Fig. 3A). Interestingly, when the mean separation analyses were performed to test the effect of temperature on the DSI of FO38 isolate at individual pH levels, 30 and $25^{\circ} \mathrm{C}$ had significantly higher levels of disease in all $\mathrm{pH}$ levels. Root rot severity at 15 and $20^{\circ} \mathrm{C}$ displayed the lowest levels of disease for all $\mathrm{pH}$ levels (Fig. 3A).

Disease levels for the nonpathogenic FO42 isolate were significantly lower than the pathogenic isolate but showed similar trends. The highest disease severity $(17.2 \%)$ was observed at the same level of $\mathrm{pH}$ and temperature as the pathogenic isolate: $\mathrm{pH} 6$ at $30^{\circ} \mathrm{C}$ (Fig. 3B). Mean separation analysis indicated no differences in disease severity between 15,20 , and $25^{\circ} \mathrm{C}$ for all $\mathrm{pH}$ levels (Fig. 3B).

Root rot symptoms differed between the pathogenic and nonpathogenic Fo isolates. Soybean seed inoculations performed with the pathogenic isolate FO38 caused extended colonization of radicles, hypocotyls, cotyledons, and tissue maceration. Subsequently, germination was lower, and soybean seedlings had poor root and shoot development (Fig. 4A to D). Conversely, inoculations performed with the nonpathogenic isolate FO42 caused a few small spots of tissue discoloration on the hypocotyls and radicles, but tissue structure and consistency were intact with no maceration or softening (Fig. 4E to $\mathrm{H})$. DSI on the noninoculated control seedlings was less than 5\%, with a few seedlings showing small spots of discoloration on the hypocotyls.

Analysis of variance also revealed significant effects of isolate for the percentage of reduction on seedling growth variables (Table 2, Fig. 5).

The highest root weight reductions were observed at $30^{\circ} \mathrm{C}$, ranging from 47 to $35 \%$, and the lowest reductions at $15^{\circ} \mathrm{C}$, ranging from 22 to $8.2 \%$, when seeds were inoculated with the pathogenic isolate FO38. Mean separation analysis indicated that the pathogenic isolate FO38 produced significant reductions on root weight at $30^{\circ} \mathrm{C}$ at $\mathrm{pH} 4$ and 5 (Fig. 5A). Conversely, seeds inoculated with the nonpathogenic FO42 isolate presented significantly lower reductions in root weight $(<20 \%)$ (Fig. 5B).

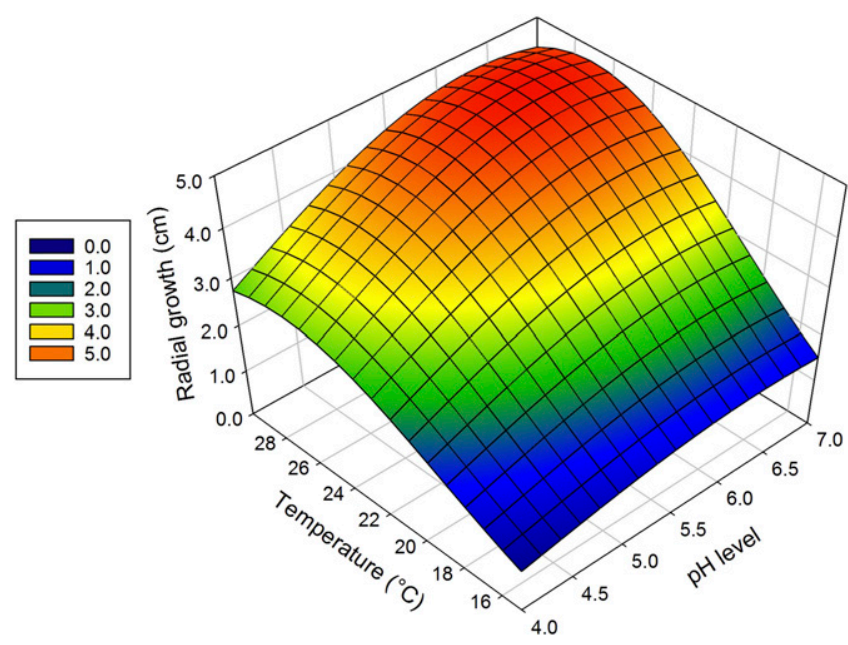

Fig. 2. Estimates of fungal radial growth $(\mathrm{cm})$ from the Gaussian regression analysis across the main factors $\mathrm{pH}$ at $4,5,6$, and 7 and temperature at $15,20,25$, and $30^{\circ} \mathrm{C}$ for the average growth of 14 Fusarium oxysporum isolates. Data represent the mean values of two experiments with four replicate Petri dishes for each treatment combination.

Table 1. Estimates of $\mathrm{pH}$ and temperature obtained from the nonlinear optimization procedure from the Gaussian model for in vitro fungal radial growth and root rot on Fusarium oxysporum isolates

\begin{tabular}{|c|c|c|c|c|c|c|c|}
\hline \multicolumn{8}{|c|}{ Gaussian model parameters and statistics for in vitro radial growth } \\
\hline Isolates & pH & Temperature $\left({ }^{\circ} \mathrm{C}\right)$ & Radial growth $(\mathbf{c m})^{\mathbf{a}}$ & $\mathbf{S E E}^{\mathbf{b}}$ & $F$ statistic & $P>F$ & Gaussian regression $R^{2 c}$ \\
\hline FO36 & 6.2 & 27.8 & 5.2 & 0.6540 & 15.8475 & 0.0002 & 0.8521 \\
\hline FO37 & 6.7 & 28.1 & 5.5 & 0.6252 & 16.3469 & 0.0001 & 0.8560 \\
\hline FO38 & 5.8 & 28.1 & 3.0 & 0.4427 & 9.9208 & 0.0001 & 0.7830 \\
\hline FO39 & 6.7 & 27.6 & 4.5 & 0.7199 & 9.1845 & 0.0016 & 0.7696 \\
\hline FO40 & 6.1 & 27.3 & 5.3 & 0.3907 & 37.3336 & $<0.0001$ & 0.9314 \\
\hline FO41 & 6.0 & 25.4 & 5.8 & 0.8204 & 11.8469 & 0.0006 & 0.8116 \\
\hline FO42 & 6.4 & 27.1 & 4.9 & 0.5791 & 17.1491 & 0.0001 & 0.8618 \\
\hline FO43 & 6.8 & 27.0 & 5.0 & 0.9150 & 6.8012 & 0.0052 & 0.7121 \\
\hline FO44 & 6.4 & 26.6 & 5.1 & 0.7169 & 13.9697 & 0.0003 & 0.8355 \\
\hline FO45 & 6.4 & 28.9 & 5.2 & 0.6895 & 16.4253 & 0.0001 & 0.8566 \\
\hline FO46 & 6.7 & 30.0 & 4.5 & 0.8193 & 7.2480 & 0.0041 & 0.7249 \\
\hline FO47 & 6.5 & 26.7 & 5.4 & 0.5334 & 23.8329 & $<0.0001$ & 0.8966 \\
\hline FO48 & 6.5 & 27.4 & 4.9 & 0.6307 & 15.3397 & 0.0002 & 0.8480 \\
\hline FO49 & 6.4 & 26.0 & 6.0 & 0.8846 & 11.1288 & 0.0007 & 0.8019 \\
\hline Average & 6.3 & 27.1 & 4.9 & 0.5792 & 17.1491 & 0.0001 & 0.8618 \\
\hline
\end{tabular}

Gaussian model parameters and statistics for root rot seedling disease

\begin{tabular}{lccccccc}
\hline Isolates & $\mathbf{p H}$ & Temperature $\left({ }^{\circ} \mathbf{C}\right)$ & DSI $(\%)^{\mathbf{a}}$ & SEE $^{\mathbf{b}}$ & $\boldsymbol{F}$ statistic & $\boldsymbol{P}>\boldsymbol{F}$ & ${\text { Gaussian regression } \boldsymbol{R}^{\mathbf{2}}}^{\mathbf{c}}$ \\
\hline FO38 & 5.9 & 30 & 64.0 & 2.9389 & 168.7979 & $<0.0001$ & 0.9840 \\
FO42 & 5.9 & 30 & 17.1 & 1.0859 & 70.2363 & $<0.0001$ & 0.9623 \\
\hline
\end{tabular}

a Maximal radial growth and maximal disease severity index (DSI) estimates were obtained by using a nonlinear optimization procedure including $\mathrm{pH}$ range from

4 to 7 and temperature range from 15 to $30^{\circ} \mathrm{C}$ for each isolate.

${ }^{\mathrm{b}} \mathrm{SEE}=$ standard error of estimate.

${ }^{\mathrm{c}} R^{2}=$ coefficient of determination. 
The highest root length reductions were observed when seeds were inoculated with the pathogenic isolate FO38 and incubated at $25^{\circ} \mathrm{C}$

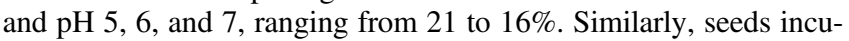
bated at $30^{\circ} \mathrm{C}$ and $\mathrm{pH} 4$ displayed a root length reduction of $20 \%$. The lowest root length reductions were observed at $15^{\circ} \mathrm{C}$, fluctuating from 8 to $6 \%$ (Fig. 5C). In contrast, seeds inoculated with the nonpathogenic FO42 isolate showed significantly lower reductions in root length $(<13 \%)$ (Fig. 5D).

Plant length reductions were the highest when seeds were inoculated with the pathogenic isolate $\mathrm{FO} 38$ and incubated at $30^{\circ} \mathrm{C}$ and $\mathrm{pH} 4$ and $6(25 \%)$. The lowest plant length reductions were observed at $15^{\circ} \mathrm{C}$, ranging from 9.3 to $4.1 \%$ (Fig. 5E). Reductions in plant length were $<9 \%$ when seeds were inoculated with the nonpathogenic FO42 isolate, with a few observations presenting no reductions (Fig. 5F).

The visual scale of severity presented similar results to DSI. The main effects of temperature and isolate were highly significant $(P<$ 0.0001 ) (Table 2), indicating that the effect of the isolates on severity depends on the temperature. DSI and the visual scale for severity were linearly related. Pearson's correlation coefficients performed separately by $F o$ isolates were highly significant $(P<0.0001)$, indicating a strong positive linear relationship (Fig. 6).

Although there were highly significant differences in the disease intensity caused by the Fo isolates, the Gaussian regression analysis described with high precision the variation in disease across $\mathrm{pH}$ levels and temperatures. Gaussian regressions performed separately on each $F o$ isolate had low standard errors of the estimates, indicating higher precision for predicted values of disease, compared with other standard models (data not shown). In addition, regression analysis showed significant $F$ statistics $(P<0.0001)$ and high coefficients of determination $\left(R^{2}\right)$, explaining 98 and $96 \%$ of the variation in disease for the pathogenic and nonpathogenic isolate, respectively (Table 1).

Estimated optimal values of $\mathrm{pH}$ and temperature for maximal root rot obtained from the Gaussian regression analysis were equivalent for the pathogenic and nonpathogenic $F o$ isolates. Interestingly, estimated values of $\mathrm{pH}$ at 5.9 and $30^{\circ} \mathrm{C}$ produced the highest level of root rot for both isolates. Under these optimal $\mathrm{pH}$ and temperature conditions, the pathogenic $F o$ isolate FO38 had a maximal estimated root rot of $64 \%$, and the nonpathogenic FO42 had a maximal estimated root rot of 17\%. (Table 1, Fig. 7).

\section{Discussion}

This study provides evidence that $\mathrm{pH}$ and temperature have significant effects on $F o$ fungal radial growth and severity of Fusarium root rot of soybean seedlings, increasing our understanding of the epidemiology of the disease. For most of the isolates, the combination of $\mathrm{pH} 6$ and $25^{\circ} \mathrm{C}$ resulted in the fastest in vitro radial growth, and the

Table 2. Analysis of variance indicating the effects of $\mathrm{pH}$ and temperature on seedling disease after inoculation of soybean seeds with pathogenic (FO38) and nonpathogenic (FO42) Fusarium oxysporum isolates in a rolled-towel assay

\begin{tabular}{|c|c|c|c|c|c|c|c|c|c|c|c|}
\hline \multirow[b]{2}{*}{ Source } & \multirow[b]{2}{*}{ df } & \multicolumn{2}{|c|}{ DSI $^{\mathbf{a}}$} & \multicolumn{2}{|c|}{ Severity } & \multicolumn{2}{|c|}{$\begin{array}{l}\text { Root weight } \\
\text { reduction (\%) }\end{array}$} & \multicolumn{2}{|c|}{$\begin{array}{c}\text { Root length } \\
\text { reduction (\%) }\end{array}$} & \multicolumn{2}{|c|}{$\begin{array}{l}\text { Plant length } \\
\text { reduction }(\%)\end{array}$} \\
\hline & & $F$ value & $P>F$ & $F$ value & $P>F$ & $F$ value & $P>F$ & $F$ value & $P>F$ & $F$ value & $P>F$ \\
\hline Replicate & 1 & 29.44 & 0.0122 & 5.87 & 0.0940 & 0.20 & 0.6818 & 1.99 & 0.1606 & 0.04 & 0.8614 \\
\hline Temperature $(\mathrm{T})$ & 3 & 57.99 & 0.0037 & 25.38 & 0.0124 & 3.29 & 0.1769 & 1.30 & 0.2768 & 0.82 & 0.5643 \\
\hline $\mathrm{pH}$ & 3 & 13.06 & $<0.0001$ & 8.78 & 0.0003 & 0.38 & 0.7708 & 2.04 & 0.1111 & 0.45 & 0.7185 \\
\hline $\mathrm{pH} \times \mathrm{T}$ & 9 & 1.90 & 0.0937 & 1.08 & 0.4048 & 2.10 & 0.0330 & 1.23 & 0.2799 & 0.70 & 0.7004 \\
\hline Isolate (I) & 1 & 326.64 & $<0.0001$ & 188.85 & $<0.0001$ & 42.60 & $<0.0001$ & 12.65 & 0.0005 & 9.88 & 0.0039 \\
\hline $\mathrm{T} \times \mathrm{I}$ & 3 & 21.88 & $<0.0001$ & 23.85 & $<0.0001$ & 7.97 & $<0.0001$ & 1.98 & 0.1195 & 2.98 & 0.0482 \\
\hline $\mathrm{pH} \times \mathrm{I}$ & 3 & 0.10 & 0.9574 & 0.44 & 0.7252 & 0.04 & 0.9909 & 0.40 & 0.7551 & 0.05 & 0.9870 \\
\hline $\mathrm{pH} \times \mathrm{T} \times \mathrm{I}$ & 9 & 0.29 & 0.9716 & 0.57 & 0.8076 & 0.18 & 0.9960 & 1.04 & 0.4110 & 0.32 & 0.9625 \\
\hline
\end{tabular}

${ }^{a}$ Disease severity index (DSI) was arcsine transformed. Visual scale of severity was square-root transformed. Percentage of reduction on seedling growth variables was calculated relative to the noninoculated control. Experiments consisted of three replications (towels) for each treatment combination and two experiments for the rolled towel assay.

A

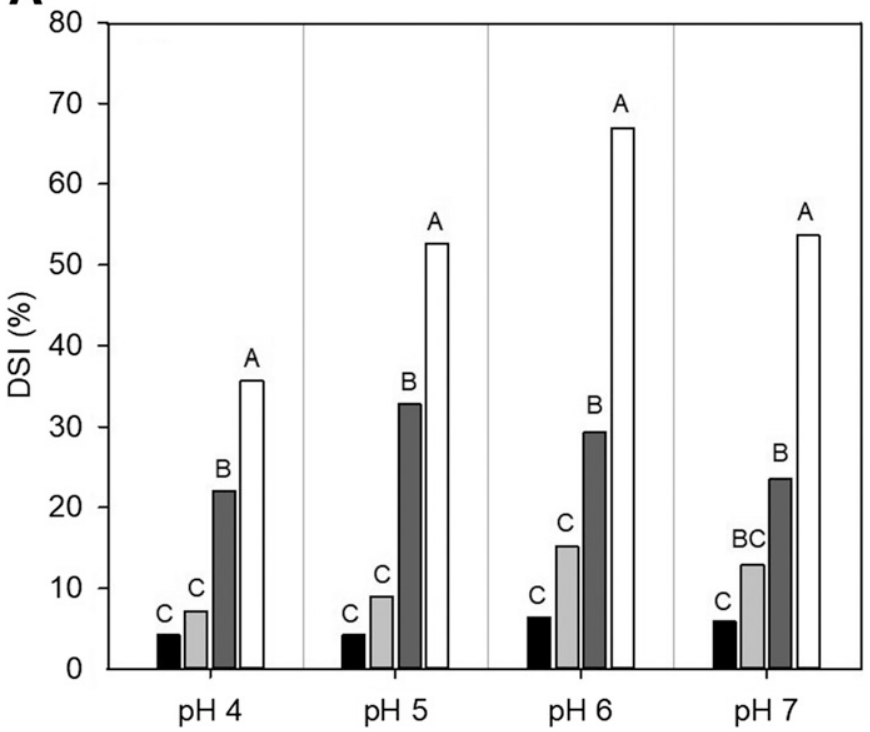

B

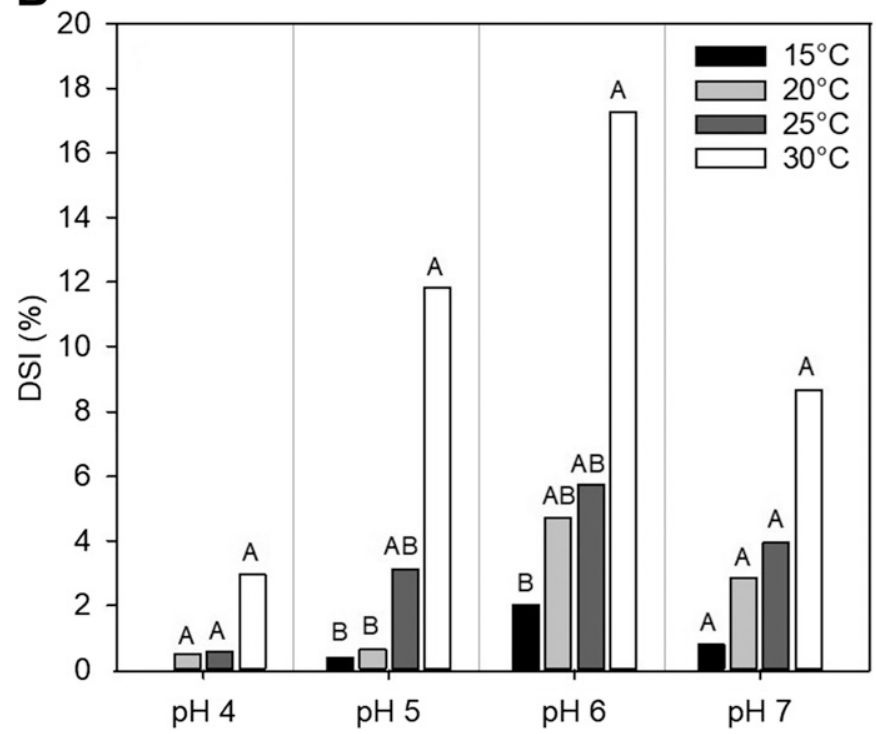

Fig. 3. Disease severity index (DSI) with respect to $\mathrm{pH}$ buffer and incubation temperature for $\mathrm{A}$, FO38 pathogenic Fusarium oxysporum ( $F$ ) isolate and $\mathrm{B}$, FO42 nonpathogenic $F o$ isolate. Comparisons were made separately by pH buffer. Means with the same letter are not significantly different according to Tukey's multiple comparison test $(P=0.05)$. 
most severe root rot development occurred at $\mathrm{pH} 6$ and $30^{\circ} \mathrm{C}$. Using Gaussian models, the optimal estimated conditions were $\mathrm{pH} 6.3$ at $27.1^{\circ} \mathrm{C}$ for maximal fungal growth and $\mathrm{pH} 5.9$ at $30^{\circ} \mathrm{C}$ for maximal root rot severity, showing that $F o$ growth and seedling disease are favored by similar conditions.

The results from this study are similar to the findings of earlier reports for in vitro radial growth of other Fusarium species and formae speciales. For example, Fo f. sp. cubense displayed a maximum radial growth at $\mathrm{pH} 6$ at $25^{\circ} \mathrm{C}$, with a minimum growth at $\mathrm{pH} 4$, using the same citrate/phosphate buffer medium (Groenewald et al. 2006). Similar results for optimal fungal growth at $25^{\circ} \mathrm{C}$ were reported for $F o$ f. sp. lactucae (Scott et al. 2010), Fo f. sp. fabae (Ivanovic et al. 1987), and Fo f. sp. spinaciae (Naiki and Morita 1983).

Growth of fungi affects the $\mathrm{pH}$ of the medium owing to the production of secondary metabolites, pigments, absorption of anions, and production of ammonia (Cochrane 1958). These metabolic activities tend to acidify the medium, as has been demonstrated in Fo (Srivastava et al. 2011), making it complex to draw conclusions when poorly buffered growth medium such as PDA is used. These results suggest that studies to determine optimal temperature for fungal growth must be viewed with some caution when PDA is used. If the fungus is able to change the $\mathrm{pH}$ of the medium to favor its growth, then conclusions about the optimal $\mathrm{pH}$ for growth could be misleading and a buffered medium must be used.

Our findings of the effect of $\mathrm{pH}$ on fungal growth and disease severity agreed with a number of studies on Fusarium spp. in which slightly acidic growth medium at around $\mathrm{pH} 6$ promotes fungal growth and sporulation (Agarwal and Sarbhoy 1978; Cochrane 1958; Groenewald et al. 2006; Gupta et al. 2010; Wu et al. 2009). However, $\mathrm{pH}$ is not a unitary factor influencing the mechanisms of growth; other physical parameters such as temperature, water potential, and relative humidity may interact to a certain degree (Cochrane 1958; Pehrson 1948). Optimal $\mathrm{pH}$ for fungal growth can change along with increasing or decreasing temperatures. For example, optimal $\mathrm{pH}$ for growth of Phacidium infestans on liquid buffered medium decreased with temperature (Pehrson 1948). This contrasts with our findings on $F o$ in which the optimal $\mathrm{pH}$ remained at 6.0 for growth across all temperatures.

Fungal growth also depends on genetic background and physiological adaptations to predominant temperatures of geographical areas (Burgess et al. 1988; Manshor et al. 2012; Walker and White 2005). Isolates from tropical regions may have higher optimal growth temperature than isolates from temperate and subtropical regions (Cochrane 1958; Nelson et al. 1990). For example, the greatest fungal radial growth tends to occur at $25^{\circ} \mathrm{C}$ for $F o$ f. sp. betae isolates collected from temperate regions in the United States (Webb et al. 2015 ), as well for $F o$ f. sp. psidii and $F$. solani isolates collected from subtropical regions in India (Gupta et al. 2010). In contrast, isolates of different Fusarium species occurring in arid and tropical regions of Australia grow the best at $30^{\circ} \mathrm{C}$ (Nelson et al. 1990; Sangalang et al. 1995). It would be interesting to include $F o$ isolates from tropical regions and compare them to those from Iowa in future $\mathrm{pH}$ and temperature studies.

Our results on root rot severity are similar to those reported for Fusarium root rot in other Fusarium species, such as Fo f. sp. dianthi, cucumerinum, cubense, ciceris, spinaciae, phaseoli, and lactucae along with $F$. graminearum (Ben-Yephet and Shtienberg 1994; Chen et al. 2013; Ellis et al. 2011; Groenewald et al. 2006; Landa et al. 2006; Naiki and Morita 1983; Schuerger and Mitchell 1992; Scott et al. 2010), in which the highest disease severity was observed at temperatures between 25 to $30^{\circ} \mathrm{C}$. Interestingly, the majority of these species were predominantly from humid subtropical climatic zones. Gaussian regression analysis indicates that pathogen fungal growth and root rot severity temperature curves have similar trends and follow each other closely, suggesting that $\mathrm{pH}$ and temperature have similar effects on Fo growth and soybean root rot severity caused by Fo.
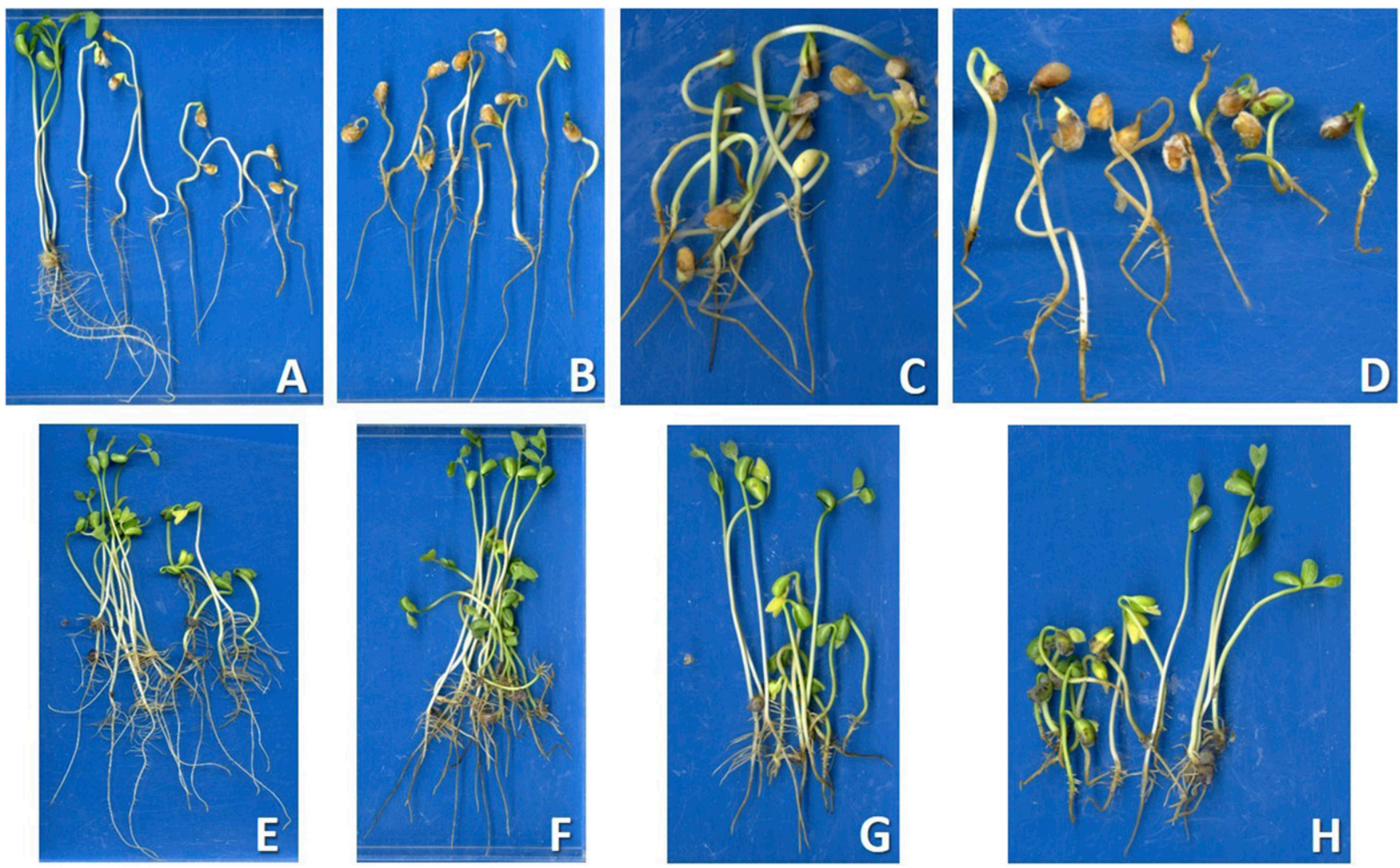

Fig. 4. Soybean seedlings incubated at $30^{\circ} \mathrm{C}$ for 8 days after seed inoculation with Fusarium oxysporum isolates with a spore suspension of $1 \times 10^{6}$ conidia/ml. A, B, C, and D, Seedlings inoculated with pathogenic isolate FO38 growing in citric acid and $\mathrm{NaOH}$ buffer set at pH 4,5,6, and 7, respectively. E, F, G, and $\mathrm{H}$, Seedlings inoculated with the nonpathogenic isolate $\mathrm{FO} 42$ growing in citric acid and $\mathrm{NaOH}$ buffer set at pH 4, 5, 6, and 7, respectively. 
Similarities in these curves might indicate that temperature influences the level of susceptibility in the host (Dickson 1923; Jones 1924).

Low temperatures have been reported to favor plant defense mechanisms making soybean seedlings more resistant to Fo (Koretsky 2001). There is evidence of overexpression of resistance-related proteins (esterase and PR-2) after soybean cultivars were inoculated with pathogenic $F o$ isolates at low temperatures. Fo-inoculated seedlings incubated at $8^{\circ} \mathrm{C}$ had higher $1,3-\beta$-glucanase activity compared with seedlings incubated at $24^{\circ} \mathrm{C}$ (Koretsky 2001). Therefore, low temperatures may favor resistance to $F o$ on soybeans, agreeing with our observations of low root rot severity and low percent reduction in seedling growth variables, such as root weight, root length, and plant length, at 15 and $20^{\circ} \mathrm{C}$ under growth chamber conditions. Root rot at temperatures between 25 and $30^{\circ} \mathrm{C}$ may be influenced by a lack
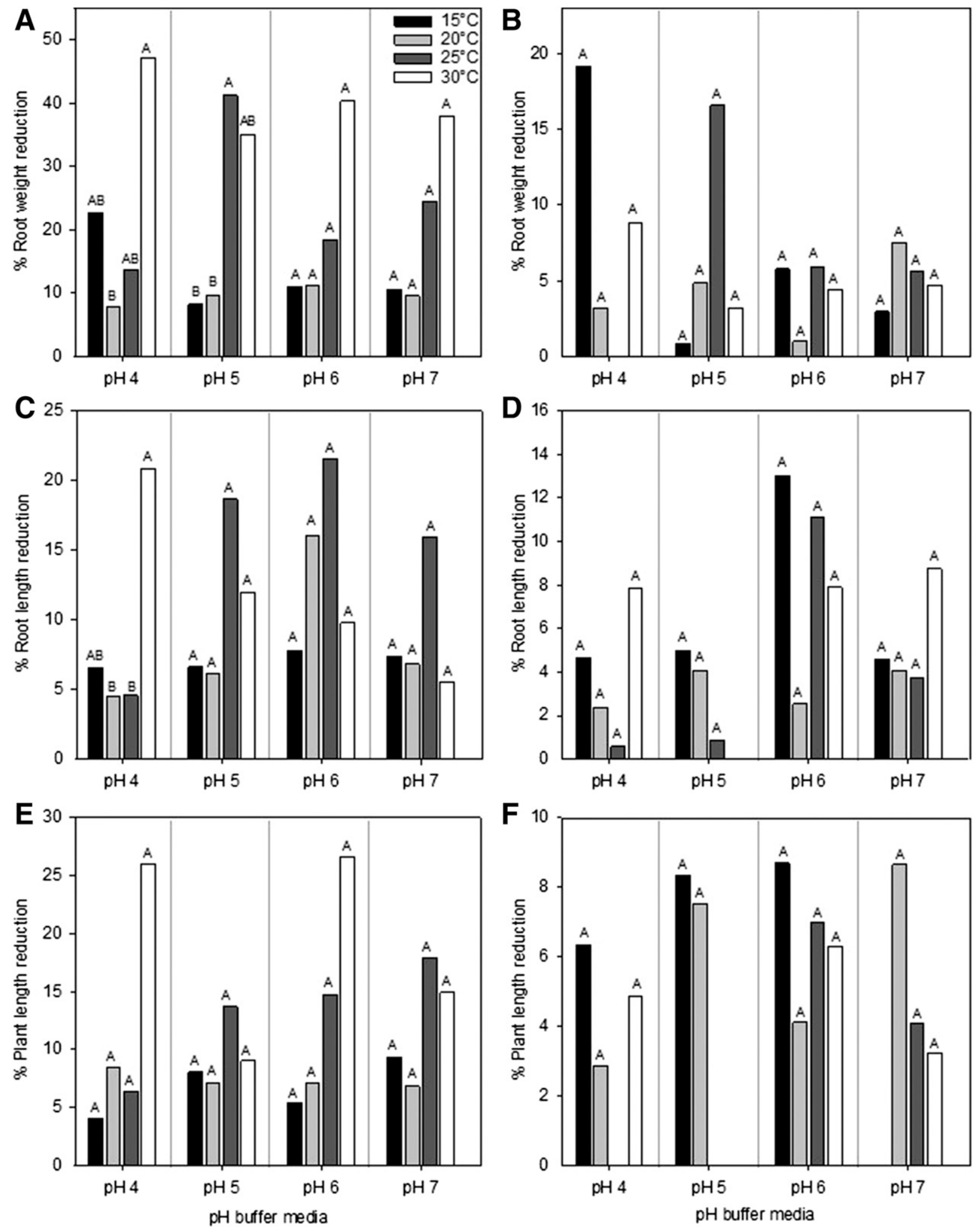

Fig. 5. Percentage of reduction on seedling growth variables relative to the noninoculated control with respect to $\mathrm{pH}$ buffer and incubation temperature for $\mathbf{A}$, $\mathbf{C}$, and $\mathbf{E}$, plants inoculated with $\mathrm{FO} 38$ pathogenic Fusarium oxysporum $(F 0)$ isolate and B, D, and F, plants inoculated with FO42 nonpathogenic Fo isolate. Comparisons were made separately by $\mathrm{pH}$ buffer. Means with the same letter are not significantly different according to Tukey's multiple comparison test $(P=0.05)$. 
of soybean resistance, which, combined with faster growth and colonization of $F o$ at its optimal growth temperature, resulted in more severe root rot. Nevertheless, these temperature-dependent defense mechanisms need further study.

Our findings regarding optimal temperature for disease development conflict with some greenhouse and field observations in which soybean root rot caused by $F o$ occurred at low temperatures $\left(<18^{\circ} \mathrm{C}\right)$ and disease severity was reduced when temperature increased from 26 to $32^{\circ} \mathrm{C}$ in $\mathrm{Fo}$-infested saturated soils (Carson et al. 1991; Farias and Griffin 1990; French 1963). A possible reason for these conflicting results is the variability in soil temperature and soil moisture under field conditions. It is important to observe the effect of various temperatures on disease development at early soybean stages. The ideal soybean germination and emergence temperatures are between 25 and $30^{\circ} \mathrm{C}$ (Hatfield and Egli 1974). Soybean planting in Iowa rarely takes place when soils are in this temperature range. However, in other regions, especially where soybean is double cropped with winter cereals, temperatures in this range may be common at planting (Dillon 2014). In Iowa, soil temperatures of 25 to $30^{\circ} \mathrm{C}$ occur during late May or early June (4 or 5 weeks after planting) (Licht et al. 2013). The usual soil temperature at planting in Iowa for late April or early May is $10^{\circ} \mathrm{C}$ (De Bruin and Pedersen 2008), and emergence takes between 7 and 14 days, increasing the risk for seedling disease. Seedling disease in soybean is usually associated with early planting and low soil temperature; under those conditions, $F o$ seems unlikely to be the primary pathogen.

Disease severity and root rot symptoms varied significantly between the pathogenic and nonpathogenic Fo isolates. Lanubile et al. (2015) demonstrated significant differences in soybean defense gene expression profiles in response to pathogenic and nonpathogenic $F_{O}$ isolates. Pathogenic $F o$ isolates induced a strong defense reaction compared with nonpathogenic, which induced relatively little host response to inoculation. These descriptions agreed with our observations on the nonpathogenic FO42 isolate, which included no symptoms of root rot, or very small black-brown discolorations on seedling roots, or hypocotyls.

The nonpathogenic isolate FO42 showed a notable ability to promote plant growth; seedlings inoculated with this isolate showed significantly higher root weight and total plant length compared with the noninoculated control. Plant growth stimulation by nonpathogenic Fo isolates has also been observed in other hosts (Fracchia et al.
A

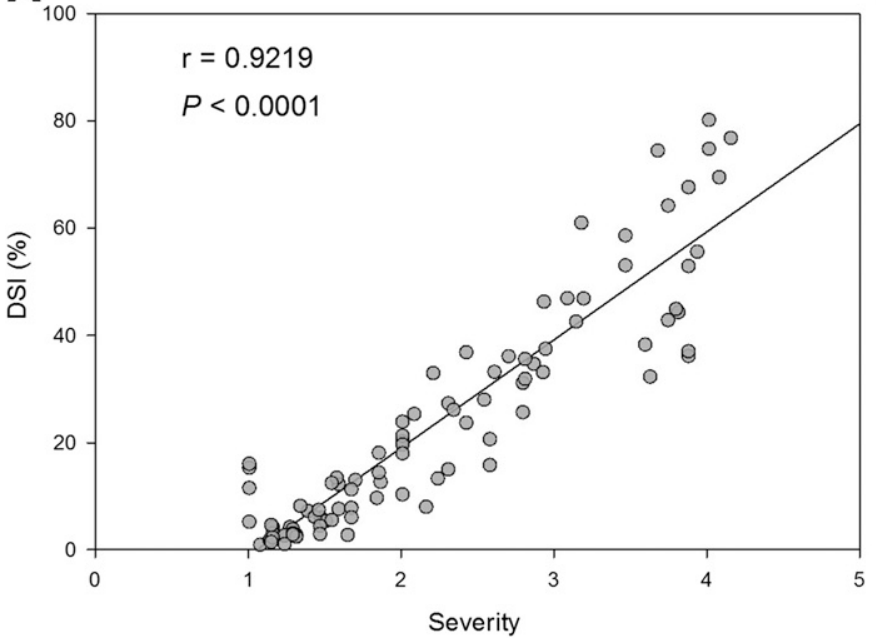

B

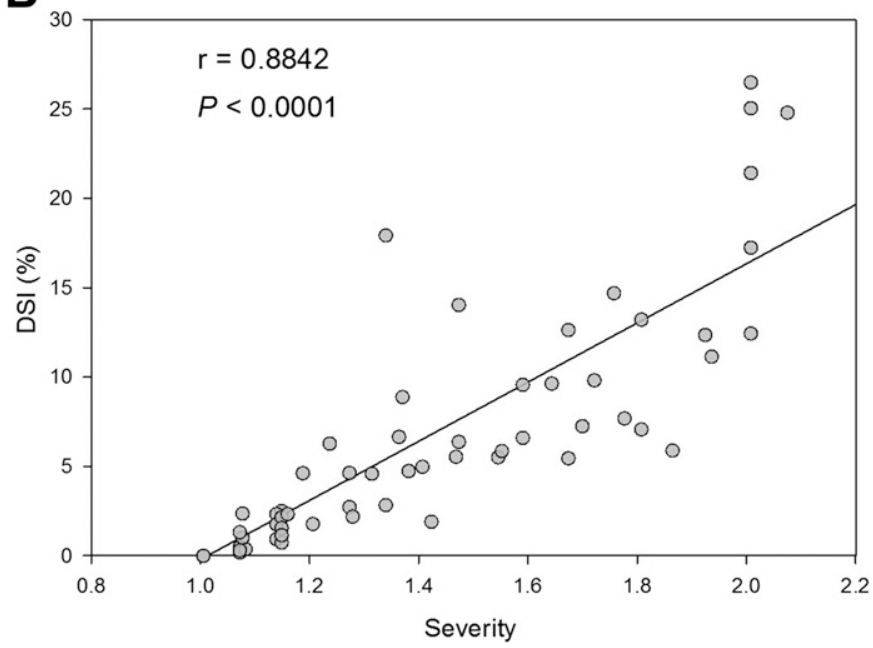

Fig. 6. Linear relationship between disease severity index (DSI) and visual scale for severity. Each data point represents the average disease of one towel containing 15 soybean seeds inoculated with A, FO38 pathogenic Fusarium oxysporum $(F o)$ isolate and B, FO42 nonpathogenic Fo isolate. Data from the noninoculated seeds were not included in the analysis. $r=$ Pearson's linear correlation coefficient.
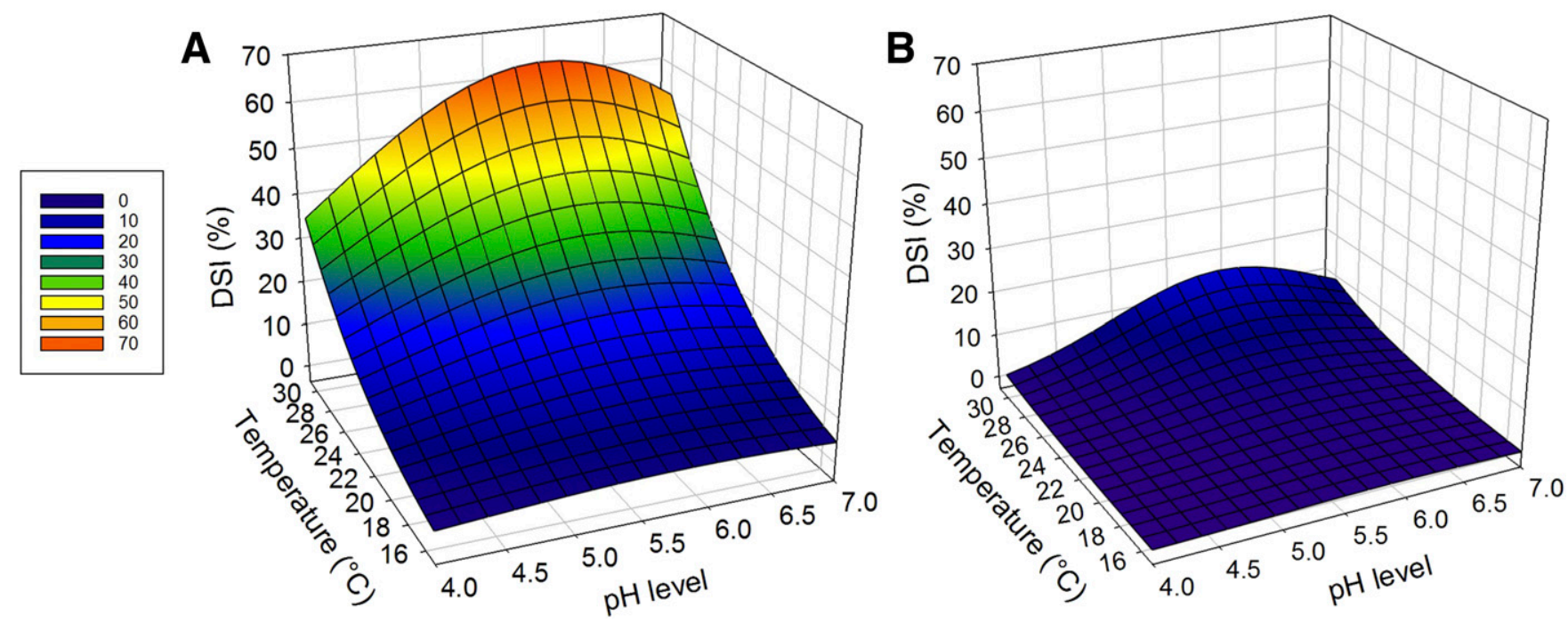

Fig. 7. Estimates of disease severity index (DSI) from the Gaussian regression analysis across the main factors $\mathrm{pH}$ at $4,5,6$, and 7 and temperature at $15,20,25$, and $30^{\circ} \mathrm{C}$ for $\mathbf{A}$, FO38 pathogenic Fusarium oxysporum $(F o)$ isolate and B, FO42 nonpathogenic Fo isolate. Data represent the disease mean values of two experimental replicates for each $F O$ isolate. 
2000; Thongkamngam and Jaenaksorn 2017). This effect has been associated with the interaction of certain fungal metabolites and volatiles with the host hormone transport and signaling of auxins (Bitas et al. 2015). Additional research on the interaction between pathogenic and nonpathogenic Fo isolates must be done to identify potential for biocontrol and how biocontrol efficacy might be influenced by abiotic factors such as $\mathrm{pH}$ and temperature in soybeans.

Although the disease severity produced by the isolates FO38 and FO42 had similar trends in response to environmental factors, severity and estimates of percent reduction in seedling growth variables for the nonpathogenic FO42 isolate were significantly lower in all combinations of $\mathrm{pH}$ and temperature compared with the pathogenic FO38 isolate. These results suggest that it is unlikely that environmental factors such as $\mathrm{pH}$ and temperature determine the potential pathogenicity of a particular $F o$ isolate. Abiotic factors influence the level of disease caused by Fo pathogenic isolates, but pathogenicity may be conferred by horizontal gene transfer of genomic regions rich in transposons or pathogenicity-related genes that contribute to the origin of different f. sp. or pathogenic genotypes (Ma et al. 2010).

This is the first report quantifying and modeling the effects of abiotic factors on $F o$ in soybeans. We found that the Gaussian model best explained the effects of temperature and $\mathrm{pH}$ on fungal radial growth and disease severity. Previous studies on Fusarium wilts in other pathosystems have used polynomial models to describe the interaction between temperature and $\mathrm{pH}$ for fungal growth in soil (Chen et al. 2013) and spore attachment under hydroponic conditions (Schuerger and Mitchell 1992). In addition, Navas-Cortés et al. (2007) developed exponential models to describe effects of soil temperature and inoculum density on Fusarium wilt of chickpea. Interestingly, these polynomial and exponential models describe trends and optimal temperatures similar to our studies of $F o$ on soybeans. The models developed for $F O$ growth and root rot will give insights on high- and low-risk scenarios to growers and farmers. This simple quantitative model captures crucial features of host-pathogen interactions on key abiotic variables such as $\mathrm{pH}$ and temperature. Additional variables could be added to create more complex and representative models.

The information generated in this research will increase knowledge about the epidemiology of $F o$ and may help to predict the risk of Fusarium root rot. This knowledge may assist breeders to better identify resistant soybean cultivars, taking into account that temperature significantly influences root rot development and Fo aggressiveness. Quantifying the impact of environmental factors on root rot disease development by the use of quantitative models may help to design more efficient management strategies by finding environmental conditions to limit disease development through the adjustment of soil $\mathrm{pH}$, planting dates, and the use of cultivars that may show a temperature-dependent reaction.

\section{Acknowledgments}

We thank S. Cianzio, C. Schmidt, and J. Orf for providing the soybean cultivars used in this study, D. A. Mayfield for technical assistance, and K. Goode for her assistance with the statistical analysis.

\section{Literature Cited}

Agarwal, D. K., and Sarbhoy, A. K. 1978. Physiological studies on four species of Fusarium pathogenic to soybean. Indian Phytopathol. 31:24-31.

Armstrong, G. M., and Armstrong, J. K. 1965. A wilt of soybean caused by a new form of Fusarium oxysporum. Phytopathology 55:237-239.

Ben-Yephet, Y., and Shtienberg, D. 1994. Effects of solar radiation and temperature on Fusarium wilt in carnation. Phytopathology 84:1416-1421.

Bitas, V., McCartney, N., Li, N., Demers, J., Kim, J.-E., Kim, H.-S., Brown, K. M., and Kang, S. 2015. Fusarium oxysporum volatiles enhance plant growth via affecting auxin transport and signaling. Front. Microbiol. 6:1248.

Brake, V. M., Pegg, K. G., Irwin, J. A. G., and Chaseling, J. 1995. The influence of temperature, inoculum level and race of Fusarium oxysporum f.sp. cubense on the disease reaction of banana cv. Cavendish. Aust. J. Agric. Res. 46:673-685.

Brownell, K. H., and Schneider, R. W. 1985. Roles of matric and osmotic components of water potential and their interaction with temperature in the growth of Fusarium oxysporum in synthetic media and soil. Phytopathology 75:53-57.

Burgess, L. W., Nelson, P. E., Toussoun, T. A., and Forbes, G. A. 1988. Distribution of Fusarium species in sections Roseum, Arthrosporiella, Gibbosum, and Discolor recovered from grassland, pasture and pine nursery soils of eastern Australia. Mycologia 80:815-824.
Byamukama, E., Robertson, A. E., and Nutter, F. W., Jr. 2011. Quantifying the within-field temporal and spatial dynamics of Bean pod mottle virus in soybean. Plant Dis. 95:126-136.

Carson, M. L., Arnold, W. E., and Todt, P. E. 1991. Predisposition of soybean seedlings to Fusarium root rot with trifluralin. Plant Dis. 75:342-347.

Chen, L. H., Huang, X. Q., Yang, X. M., and Shen, Q. R. 2013. Modeling the effects of environmental factors on the population of Fusarium oxysporum in cucumber continuously cropped soil. Commun. Soil Sci. Plant Anal. 44 2219-2232.

Cochrane, V. 1958. Cultivation and growth. Pages 1-27 in: Physiology of Fungi Wiley, New York, NY.

Cruz Jimenez, D. R., Ellis, M. L., Munkvold, G. P., and Leandro, L. F. S. 2018 Isolate-cultivar interactions, in vitro growth, and fungicide sensitivity of Fusarium oxysporum isolates causing seedling disease on soybean. Plant Dis. 102:1928-1937.

Datnoff, L. E., and Sinclair, J. B. 1988. The interaction of Fusarium oxysporum and Rhizoctonia solani in causing root rot of soybeans. Phytopathology 78: 771-777

De Bruin, J. L., and Pedersen, P. 2008. Soybean seed yield response to planting date and seeding rate in the Upper Midwest. Agron. J. 100:696-703.

Díaz Arias, M. M., Leandro, L. F., and Munkvold, G. P. 2013a. Aggressiveness of Fusarium species and impact of root infection on growth and yield of soybeans. Phytopathology 103:822-832.

Díaz Arias, M. M., Munkvold, G. P., Ellis, M. L., and Leandro, L. F. S. 2013b. Distribution and frequency of Fusarium species associated with soybean roots in Iowa. Plant Dis. 97:1557-1562.

Dickson, J. G. 1923. Influence of soil temperature and moisture on the development of the seedling-blight of wheat and corn caused by Gibberella saubinetii. J. Agric. Res. 23:837-870.

Dillon, K. A. 2014. Double-crop soybean vegetative growth, seed yield, and yield component response to agronomic inputs in the Mid-Atlantic, USA. Ph.D. dissertation. Virginia Polytechnic Institute \& State University, Suffolk, VA.

Ellis, M. L., Broders, K. D., Paul, P. A., and Dorrance, A. E. 2011. Infection of soybean seed by Fusarium graminearum and effect of seed treatments on disease under controlled conditions. Plant Dis. 95:401-407.

Ellis, M. L., Cruz, D. R., Leandro, L. F., and Munkvold, G. P. 2014. Genotypic and phenotypic characterization of fungi in the Fusarium oxysporum species complex from soybean roots. Phytopathology 104:1329-1339.

Farias, G. M., and Griffin, G. J. 1990. Extent and pattern of early soybean seedling colonization by Fusarium oxysporum and $F$. solani in natural infested soil. Plant Soil 123:59-65.

Fracchia, S., Garcia-Romera, I., Godeas, A., and Ocampo, J. A. 2000. Effect of the saprophytic fungus Fusarium oxysporum on arbuscular mycorrhizal colonization and growth of plants in greenhouse and field trials. Plant Soil 223:177-186.

French, E. R. 1963. Effect of soil temperature and moisture on the development of Fusarium root rot of Soybean. Phytopathology 53:875.

Gatch, E. W., and du Toit, L. J. 2017. Limestone-mediated suppression of Fusarium wilt in spinach seed crops. Plant Dis. 101:81-94.

Groenewald, S., van den Berg, N., Marasas, W. F. O., and Viljoen, A. 2006. Biological, physiological and pathogenic variation in a genetically homogenous population of Fusarium oxysporum f.sp. cubense. Austral. Plant Pathol. 35: 401-409.

Gupta, V. K., Misra, A. K., and Gaur, R. K. 2010. Growth characteristics of Fusarium spp. causing wilt disease in Psidium guajava L. in India. J. Plant Prot. Res. 50:452-462.

Harling, R., Taylor, G. S., Matthews, P., and Arthur, A. E. 1988. The effect of temperature on symptom expression and colonization in resistant and susceptible carnation cultivars infected with Fusarium oxysporum f.sp. dianthi. J. Phytopathol. 121:103-117.

Hatfield, J. L., and Egli, D. B. 1974. Effect of temperature on the rate of soybean hypocotyl elongation and field emergence. Crop Sci. 14:423-426.

Ivanovic, M., Dragicevic, O., and Ivanovic, D. 1987. Fusarium oxysporum f.sp. fabae as cause of root rot on broad bean in Yugoslavia. Zastita Bilja 38:373-380.

Jones, L. R. 1924. The relation of environment to disease in plants. Am. J. Bot. 11: 601-609.

Koretsky, L. S. 2001. The influence of Fusarium oxysporum infection and low temperatures on the activity of soybean esterase and PR proteins. Icel. Agric. Sci. 14:67-73.

Landa, B. B., Navas-Cortes, J. A., Jimenez-Gasco, M. D., Katan, J., Refig, B., and Jimenez-Diaz, R. M. 2006. Temperature response of chickpea cultivars to races of Fusarium oxysporum $\mathrm{f}$. sp. ciceris, causal agent of Fusarium wilt. Plant Dis. 90:365-374.

Lanubile, A., Muppirala, U. K., Severin, A. J., Marocco, A., and Munkvold, G. P. 2015. Transcriptome profiling of soybean (Glycine max) roots challenged with pathogenic and non-pathogenic isolates of Fusarium oxysporum. BMC Genomics 16:1089-1102.

Leath, S., and Carroll, R. B. 1982. Screening for resistance to Fusarium oxysporum in soybean. Plant Dis. 66:1140-1143.

Licht, M. A., Wright, D., and Lenssen, A. W. 2013. Planting Soybean for High Yield in Iowa. Agriculture and Environment Extension Publications 193. Iowa State University Extension and Outreach, Ames, IA. https://lib.dr.iastate.edu/ extension ag pubs/193 
Ma, L. J., van der Does, H. C., Borkovich, K. A., Coleman, J. J., Daboussi, M. J., Di Pietro, A., Dufresne, M., Freitag, M., Grabherr, M., Henrissat, B., Houterman, P. M., Kang, S., Shim, W. B., Woloshuk, C., Xie, X. H., Xu, J. R., Antoniw, J., Baker, S. E., Bluhm, B. H., Breakspear, A., Brown, D. W., Butchko, R. A. E., Chapman, S., Coulson, R., Coutinho, P. M., Danchin, E. G. J., Diener, A., Gale, L. R., Gardiner, D. M., Goff, S., Hammond-Kosack, K. E., Hilburn, K., Hua-Van, A., Jonkers, W., Kazan, K., Kodira, C. D., Koehrsen, M., Kumar, L., Lee, Y. H., Li, L. D., Manners, J. M., Miranda-Saavedra, D., Mukherjee, M., Park, G., Park, J., Park, S. Y., Proctor, R. H., Regev, A., Ruiz-Roldan, M. C., Sain, D., Sakthikumar, S., Sykes, S., Schwartz, D. C., Turgeon, B. G., Wapinski, I., Yoder, O., Young, S., Zeng, Q. D., Zhou, S. G., Galagan, J., Cuomo, C. A., Kistler, H. C., and Rep, M. 2010. Comparative genomics reveals mobile pathogenicity chromosomes in Fusarium. Nature 464:367-373.

Manshor, N., Rosli, H., Ismail, N. A., Salleh, B., and Zakaria, L. 2012. Diversity of Fusarium species from highland areas in Malaysia. Trop. Life Sci. Res. 23:1-15.

Marin, S., Sanchis, V., and Magan, N. 1995. Water activity, temperature, and pH effects on growth of Fusarium moniliforme and Fusarium proliferatum isolates from maize. Can. J. Microbiol. 41:1063-1070.

Miller, D. E., and Burke, D. W. 1985. Effects of soil physical factors on resistance in beans to Fusarium root rot. Plant Dis. 69:324-327.

Naiki, T., and Morita, Y. 1983. The population of spinach wilt fungus, Fusarium oxysporum f. sp. spinaciae, and the wilt incidence in soil. Ann. Phytopathol. Soc. Jpn. 49:539-544.

Navas-Cortés, J. A., Landa, B. B., Mendez-Rodriguez, M. A., and Jimenez-Diaz, R. M. 2007. Quantitative modeling of the effects of temperature and inoculum density of Fusarium oxysporum f. sp. ciceris races 0 and 5 on development of Fusarium wilt in chickpea cultivars. Phytopathology 97:564-573.

Nelson, P. E., Burgess, L. W., and Summerell, B. A. 1990. Some morphological and physiological characters of Fusarium species in section Liseola and Elegans and similar species. Mycologia 82:99-106.

Paulitz, T. C., Dutilleul, P., Yamasaki, S. H., Fernando, W. G. D., and Seaman, W. L. 1999. A generalized two-dimensional Gaussian model of disease foci of head blight of wheat caused by Gibberella zeae. Phytopathology 89:74-83.

Pehrson, S. O. 1948. Studies of the growth physiology of Phacidium infestans Karst. Physiol. Plant. 1:38-56.

Prussin, A. J., Marr, L. C., Schmale, D. G., Stoll, R., and Ross, S. D. 2015. Experimental validation of a long-distance transport model for plant pathogens: Application to Fusarium graminearum. Agric. For. Meteorol. 203:118-130.

Sangalang, A. E., Backhouse, D., and Burgess, L. W. 1995. Survival and growth in culture of four Fusarium species in relation to occurrence in soils from hot climatic regions. Mycol. Res. 99:529-533.

Schuerger, A. C., and Mitchell, D. J. 1992. Effects of temperature and hydrogen ion concentration on attachment of macroconidia of Fusarium solani f.sp. phaseoli to mung bean roots in hydroponic nutrient solution. Phytopathology 82:1311-1319.

Scott, J. C., Gordon, T. R., Shaw, D. V., and Koike, S. T. 2010. Effect of temperature on severity of Fusarium wilt of lettuce caused by Fusarium oxysporum f. sp. lactucae. Plant Dis. 94:13-17.

Skelsey, P., Holtslag, A. A. M., and van der Werf, W. 2008. Development and validation of a quasi-Gaussian plume model for the transport of botanical spores. Agric. For. Meteorol. 148:1383-1394.

Soubeyrand, S., Enjalbert, J., and Sache, I. 2008. Accounting for roughness of circular processes: Using Gaussian random processes to model the anisotropic spread of airborne plant disease. Theor. Popul. Biol. 73: 92-103.

Spijkerboer, H. P., Beniers, J. E., Jaspers, D., Schouten, H. J., Goudriaan, J., Rabbinge, R., and van der Werf, W. 2002. Ability of the Gaussian plume model to predict and describe spore dispersal over a potato crop. Ecol. Modell. 155:1-18.

Srivastava, S., Pathak, N., and Srivastava, P. 2011. Identification of limiting factors for the optimum growth of Fusarium oxysporum in liquid medium. Toxicol. Int. 18:111-116.

Srobar, S. 1978. The influence of temperature and $\mathrm{pH}$ on the growth of mycelium of the causative agents of fusarioses in wheat in Slovakia Czechoslovakia. Plan Prot. Sci. 14:269-274.

Stuthman, D. D., Leonard, K. J., and Miller-Garvin, J. 2007. Breeding crops for durable resistance to disease. Pages 319-367 in: Advances in Agronomy. D. L. Sparks, ed. Vol. 95. Elsevier Academic Press, San Diego, CA.

Thongkamngam, T., and Jaenaksorn, T. 2017. Fusarium oxysporum (F221-B) as biocontrol agent against plant pathogenic fungi in vitro and in hydroponics. Plant Prot. Sci. 53:85-95.

Walker, G. P., and White, N. A. 2005. Introduction to fungal physiology. Pages 1-34 in: Fungi: Biology and Applications. K. Kavanagh, ed. Wiley, West Sussex, England.

Webb, K. M., Brenner, T., and Jacobsen, B. J. 2015. Temperature effects on the interactions of sugar beet with Fusarium yellows caused by Fusarium oxysporum f. sp. betae. Can. J. Plant Pathol. 37:353-362.

Wetzstein, H. Y., Kim, C., and Sommer, H. E. 1994. Vessel volume, gelling agent, and basal salts affect $\mathrm{pH}$ and gel strength of autoclaved tissue-culture media. HortScience 29:683-685.

Wu, H. S., Wang, Y., Zhang, C. Y., Bao, W., Ling, N., Liu, D. Y., and Shen, Q. R. 2009. Growth of in vitro Fusarium oxysporum f. sp. niveum in chemically defined media amended with gallic acid. Biol. Res. 42:297-304.

Yamamoto, F., and Cunha, R. 2007. Acid gelation of gellan: Effect of final pH and heat treatment conditions. Carbohydr. Polym. 68:517-527.

Zhang, J. X., Xue, A. G., Zhang, H. J., Nagasawa, A. E., and Tambong, J. T. 2010 Response of soybean cultivars to root rot caused by Fusarium species. Can. J. Plant Sci. 90:767-776. 